\title{
The process of smart city definition at an EU level
}

\author{
F. Russo, C. Rindone \& P. Panuccio \\ DIIES - Dipartimento di ingegneria dell'Informazione, \\ delle Infrastrutture e dell'Energia Sostenibile, \\ Università degli Studi Mediterranea di Reggio Calabria, Italy
}

\begin{abstract}
Diffusion and availability of new technologies has influenced the evolution and organization of cities. New technologies and services, in particular in the areas of transport, energy and ICT, are requirements to transform a city into a smart city contributing towards reaching a high level of urban sustainable development.

The purpose of this paper is to analyse the process of smart city definition following the European approach. In the context of the European Union's ten-year growth and jobs strategy (Europe 2020 strategy), the role of smart cities is defined. The main European objective is to tackle the major societal challenges at an urban level, adopting smart cities' solutions. The European Commission proposes an integrated approach to connect policies and resources at EU, national, regional and local levels to promote smart cities' solutions.

Keywords: urban planning, European policies, innovation, smart city, research funding.
\end{abstract}

\section{Introduction}

Modern cities face new challenges caused by the globalization and the integration process (increased population; increased pollution; climate change; limited natural resources).

Globalization and technological changes influence city evolution. The new challenges combine competitiveness and sustainable urban development simultaneously [1]. 
The planning process has to include smart city concepts to draw the new city. However, in literature there are numerous definitions and many ways to be smart $[2,3]$.

In this paper the European way to smart cities' solutions is focused on.

In Europe the level of urbanization is above $75 \%$, to rise to $80 \%$ by 2020 , with cities consuming over $70 \%$ of energy and emitting as much of greenhouse gases in the EU. To tackle these challenges, Europe is implementing a process to define and to fund smart city solutions for pursuing the 2020 targets [4].

Smart cities require new, efficient, and user-friendly technologies and services in particular in the areas of transport, energy and ICT [5]. The European Union is investing in research and innovation and developing policies about smart cities to achieve a triple bottom line gain for Europe: better quality of life for citizens, more competitive industry and SMEs, and more sustainable energy, transport and ICT systems and infrastructures [6].

After this introduction, the paper has three sections: in section 2, principal definitions of a smart city are recalled; in section 3, the main steps of the EU process are proposed; in section 4 , the EU smart city initiatives and funding are reported.

\section{The last main smart city definitions}

The smart concept has been gradually advanced from a material (micro) object to the whole city considered as a holistic system.

The term smart city is used in multidisciplinary topics. Each topic adopts owner language, defining actions to pursue specific objectives. Then there is no definition that includes all aspects of the smart city.

In the context of international debate about smart cities, principal recent definitions are reported in the following.

The first use of term smart city was in 2007 [1].

The idea of smart cities is rooted in the creation and connection of human capital, social capital and Information and Communication Technology (ICT) infrastructure in order to generate a greater and more sustainable economic development and a better quality of life.

In 2008 a little advanced definition could be found. Smart City uses the network infrastructure to improve economic and political efficiency, and to allow the social, cultural and urban development [7].

In 2011 an extension is proposed. A city may be called 'smart' when investments in human and social capital and traditional and modern communication infrastructure fuel sustainable economic growth and a high quality of life, with a wise management of natural resources, through participatory governance [8].

In a Smart City, networks are linked together, supporting and positively feeding off each other, so that the technology and data gathering should: be able to constantly gather, analyse and distribute data about the city to optimise efficiency and effectiveness in the pursuit of competitiveness and sustainability; be able to communicate and share such data and information around the city using common 
definitions and standards so it can be easily re-used; be able to act multifunctionally, which means they should provide solutions to multiple problems from a holistic city perspective [2].

A first complete definition in terms of system is given in 2013. Smart Cities should be seen as systems of systems, and that there are emerging opportunities to introduce digital nervous systems, intelligent responsiveness, and optimization at every level of system integration [9].

A smart city uses information and communications technology (ICT) to enhance its livability, workability and sustainability. In simplest terms, there are three parts to that job: collecting, communicating and "crunching." First, a smart city collects information about itself through sensors, other devices and existing systems. Next, it communicates that data using wired or wireless networks. Third, it "crunches" (analyzes) that data to understand what's happening now and what's likely to happen next [10].

Smart city is an expression introduced into the official Italian lexicon in 2013. The concept couples cities' material infrastructures with intellectual, social and human capital of inhabitants [11].

A Smart City consists of not only components but also people. Securing the participation of citizens and relevant stakeholders in the Smart City is therefore another success factor. There is a difference if the participation follows a topdown or a bottom-up approach. A top-down approach promotes a high degree of coordination, whereas a bottom-up approach allows more opportunity for people to participate directly [12].

Definitions can be classified referring to: input, activities and outputs to implement a smart city; objectives (outcomes and goals) to reach implementing smart city solutions.

\section{Main steps in the smart city European process}

At the same time of the theoretical debate on smart city definition, a large process of implementation has been developed by EU organisms. The implementation, some time, wins on the formal definition. In the following a tree from which emerges the EU smart city products, is built and analysed.

\subsection{European Union 2020 strategy}

The European Union's ten-year growth and jobs strategy (Europe 2020 strategy) was launched in 2010, considering the long terms trends affecting growth (societal change, globalization, productivity developments, information and communication technologies...).

The strategy is declined into three priorities for the growth and seven flagship initiatives [4]:

- smart growth, in terms of effective investments in education, research and innovation; the connected flagship initiatives are innovation union, digital agenda for Europe, youth on the move; 
- sustainable growth, in terms of actions to move towards a low-carbon economy; the connected flagship initiatives are resource efficient Europe, an industrial policy for the globalisation era;

- inclusive growth, in terms of actions to create jobs and to reduce poverty; the connected flagship initiatives are an agenda for new skills and jobs, European platform against poverty.

Five measurable headline targets for Europe 2020 are defined for employment, for research and innovation, for climate change and energy, for education and for combating poverty. Targets represent a success help to measure and guide the different aspects of the strategy, at both national and EU level.

The Europe 2020 strategy and its flagship initiatives are the reference points to address investments in education, research and innovation for achieving the headline targets related to the growth [4].

\subsection{Innovation Union flagship initiative}

The Innovation Union flagship initiative, together with the Digital Agenda [13], Industrial Policy and Resource Efficient Europe flagships, and the Single Market Act, create the best conditions for Europe's researchers and entrepreneurs to innovate [14].

To develop the Innovation Union flagship initiative, two stakeholders' advisory platforms are defined:

- European Technology Platforms (ETPs) that are industry-led stakeholder forum with the aim to define medium to long-term research and technological objectives, also developing roadmaps to achieve them (industry-driven) [15];

- European Innovation Partnerships (EIPs) that is a new approach to EU research and innovation for bringing together public and private stakeholders to accelerate the deployment of major innovations by committing them to undertaking supply and demand side measures (funding, regulation, standards, procurements etc.) across sectors and the entire innovation system (demand-driven); the areas of EIPs are: Active and Healthy Ageing (EIPAHA); Agricultural Sustainability and Productivity (EIP-AGRI); Smart Cities and Communities (EIP-SCC); Water (EIP-W); Raw Materials (EIP-RM) [16]. In the following we focus on EIP-SCC.

\subsection{European Innovation Partnership for Smart Cities and Communities (EIP-SCC)}

The European Innovation Partnership for Smart Cities and Communities (EIPSCC) brings together cities, industry and citizens to improve urban life through more sustainable integrated solutions. The partnership, across the focus areas of energy, transport and information and communication technologies (ICT), has the main objective to catalyze progress in these intimately linked areas and to offer new interdisciplinary opportunities to improve services reducing energy and resource consumption (Figure 1). The partnership includes applied innovation, better planning, a more participatory approach, higher energy efficiency, better 


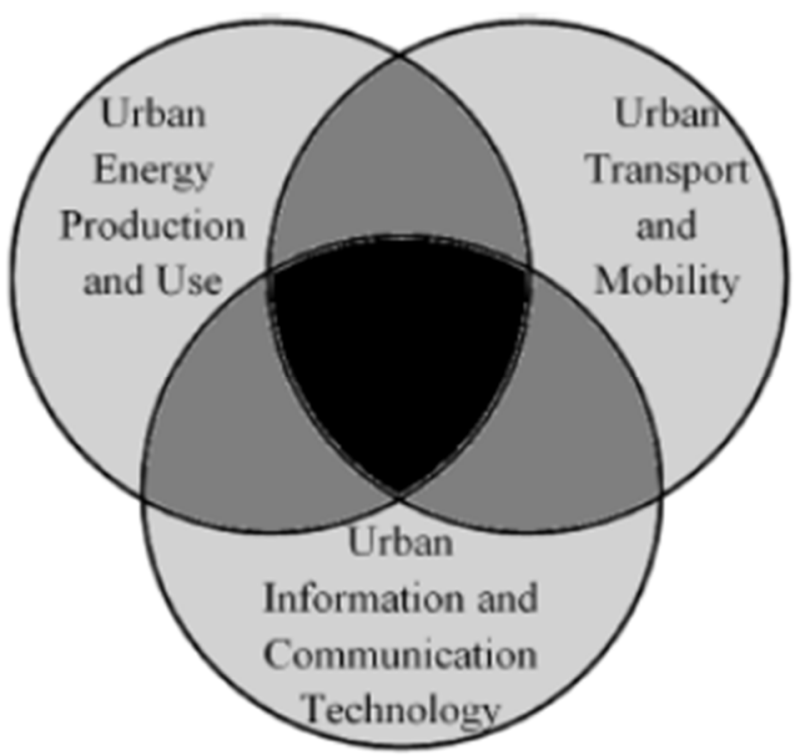

Figure 1: The EIP-SCC focus areas [5].

transport solutions, intelligent use of Information and Communication Technologies (ICT), etc. [5].

In the first step on 2012, EIP-SCC has oriented the Seventh Framework Programme (FP7) - 2013 Work Programme to reflect the integrated nature of the urban energy, transport and ICT topics [5].

Further implementations of smart cities are oriented by governance bodies of EIP-SCC [17]:

- the High Level Group (HLG) that comprehends the high level representatives from industry, research and cities; HLG is supported by Sherpa Group that is formed by HLG representative and a set of additional associated members; HLG will be led by the three Commissioners for Energy, Transport and Digital Agenda;

- the Smart Cities Stakeholder Platform (SCSP) that is a collaborative, networking and knowledge sharing tool of EIP-SCC; is established in 2011; SCSP has two principal aims:

i) identifying and spreading relevant information on technology solutions and needs required by practitioners and

ii) providing information for policy support to the High Level Group and the European Commission.

The two interconnected governance bodies incorporate inputs from relevant stakeholders. SCSP, together with the High Level Group, from a bottom-up perspective, contributes to the discussion about Smart Cities in Europe. 


\subsection{Strategic and Operational Implementation Plans (SIP/OIP)}

Governance bodies (HLG, supported by Sherpa group and SCSP) produce guidelines to implement SCC initiative: the Strategic Implementation Plan (SIP), adopted in 2013 [18], and the Operational Implementation Plan (OIP), drafted in 2014 [19].

The EIP-SCC and their implementation plans are neither a new funding programme nor instrument nor a legal entity. SIP and OIP helps to define how concepts promoting smart cities are put into practice.

The strategic plan has individuated [18]:

- Three specific vertical areas: (1) Sustainable Urban Mobility - Alternative energies, public transport, efficient logistics, planning; (2) Sustainable Districts and Built Environment - improving the energy efficiency of buildings and districts, increasing the share of renewable energy sources used and the liveability of our communities; and (3) Integrated Infrastructures and processes across Energy, ICT and Transport - connecting infrastructure assets to improve the efficiency and sustainability of cities.

- Eight horizontal enabling themes grouped into three classes: Decisions (1citizen focus, 2-policy and regulation, 3-integrated planning), Insight (4knowledge sharing, 5-metrics and indicators, 6-open data, 7-standards), and Funds (8-business models, procurement and funding).

In 2014, the European Commission has launched an open Invitation for Commitment under the EIP-SCC. A commitment is an intention to provide a measurable and concrete engagement in support of one or more focus areas in the course of the next year and beyond. The interested parties (e.g. members of principal cities networks such as the Green Digital Charter, the Covenant of Mayors, the Smart Cities Stakeholder Platform as well as CIVITAS) are invited to respond to this invitation to step forward and support the objectives of the EIPSCC by communicating and sharing their plans and initiatives for actions at the interface of energy, transport and information and communication technologies and infrastructures [20].

A representation of the smart city European process is illustrated in Figure 2.

\section{European Commission initiatives and funding for smart cities}

The EU is dedicating specific funding instruments to implement smart cities. The complementarity among EU budget funds (e.g. the EU Cohesion Policy, together with the EU's Competitiveness and Innovation Funds), European Investment Bank (EIB)'s financial instruments and private investments allow the development of integrated energy, transport and ICT investments for smart cities [21].

Two main kinds of initiatives are available to implement smart cities solutions (Figure 3):

- lighthouse projects and activities that could be partly financed by the H2020 [22]; 
- other projects and activities that could be financed by other private and public funding sources (for example the European structural and investment funds) to spread smart cities solutions to other cities [6].

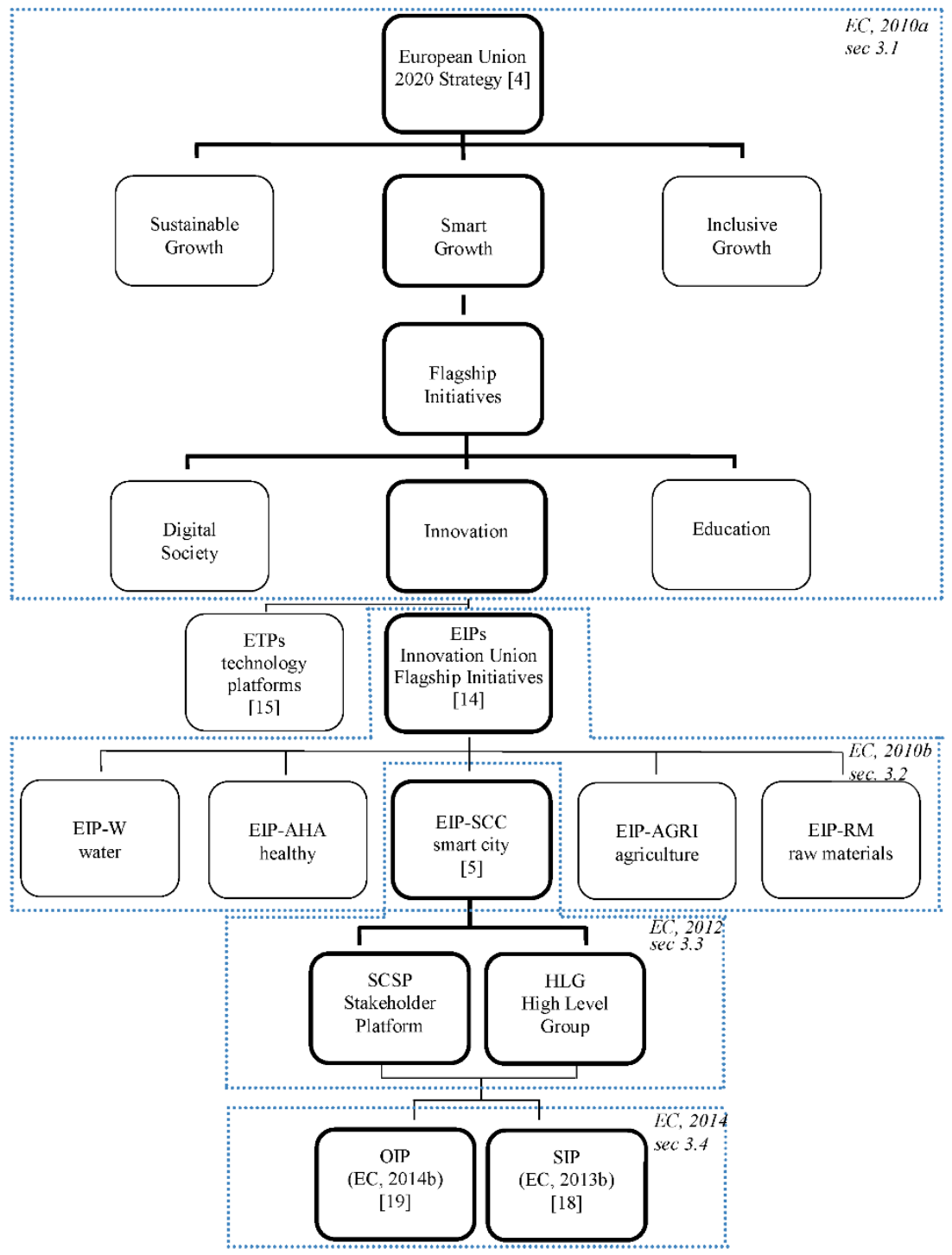

Figure 2: The smart city European process. 


\subsection{Lighthouse projects on Horizon 2020}

EIP-SCC, with their implementation plans (SIP, OIP), is orienting smart cities solutions. This partnership will be fully operational under the research and innovation funding framework Horizon 2020 (H2020), in the context of the Multiannual Financing Framework (MFF 2014-2020). For instance, in the H2020 Work Programme for the years 2014-15 (Figure 4), the budget dedicated to smart cities initiatives, is about EUR 200 million of which EUR 92,32 million from the 2014 and EUR 108,18 million from the 2015 [22]. Lighthouse projects, partly financed by the H2020, follow the recommendations of the SIP. These projects are large scale demonstrations that can be replicated in a city context where existing or near to market technology will be integrated in an innovative way; lighthouse projects in H2020 [22] comprehend these areas: low energy districts; integrated infrastructures; sustainable urban mobility.

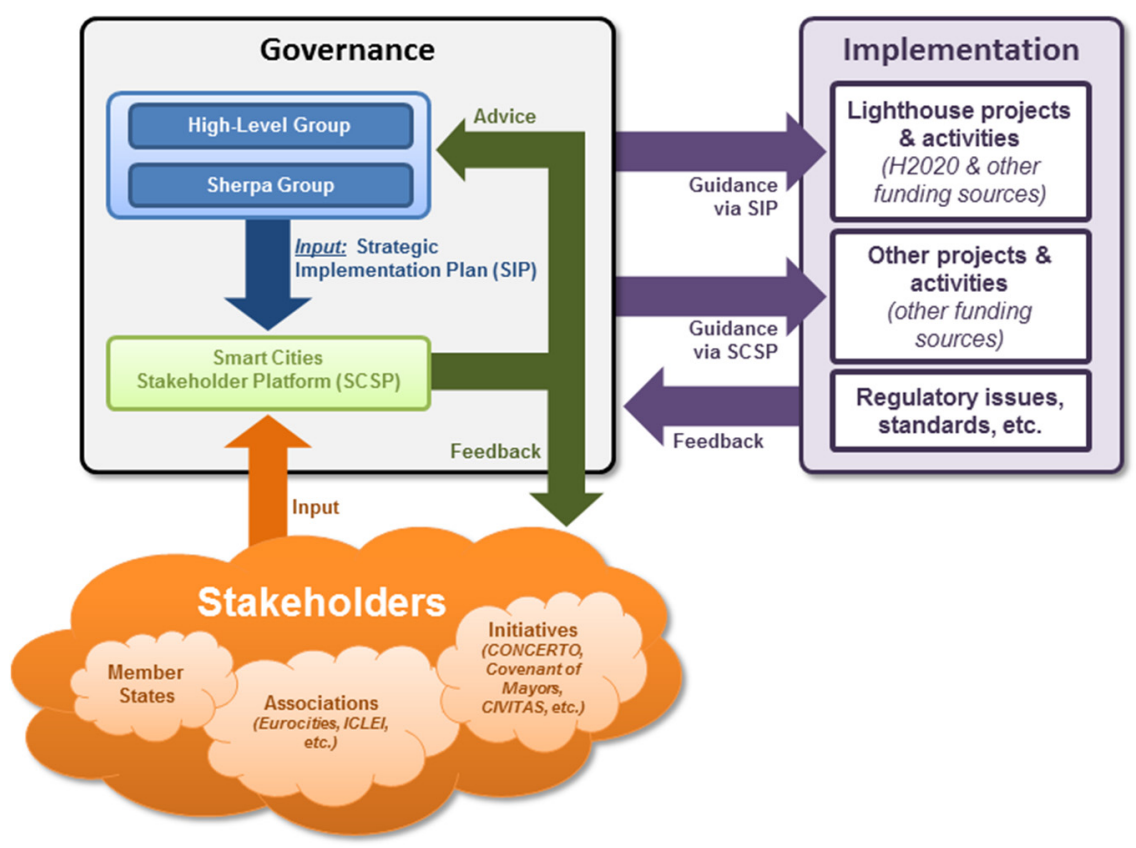

Figure 3: EIP-SCC Governance bodies to influence implementation of smart cities [17].

\subsection{Other projects and activities}

Other funding sources dedicated to smart cities development have been launched for the period 2007-2013. The principal financial initiatives are extended for the period 2014-2020 (EC, 2013c) [21]: 
- JESSICA (Joint European Support for Sustainable Investment in City Areas) that is a policy initiative of the European Commission (EC) developed jointly with the EIB and in collaboration with the Council of Europe Development Bank (CEB);

- the Risk Sharing Financing Facility (RSFF) that is a Joint Financial Instrument (JFI) created in 2007 jointly between EC and the EIB; the financial instrument has been renewed for the period 2014-2020; urban projects with an innovative character are in principle eligible for RSFF financing;

- ELENA (European Local ENergy Assistance) that consists of a technical assistance facility, financed through the (Intelligent Energy Europe) IEE, support for the preparation of quality projects in the fields of energy efficiency and renewable energy sources in urban areas.

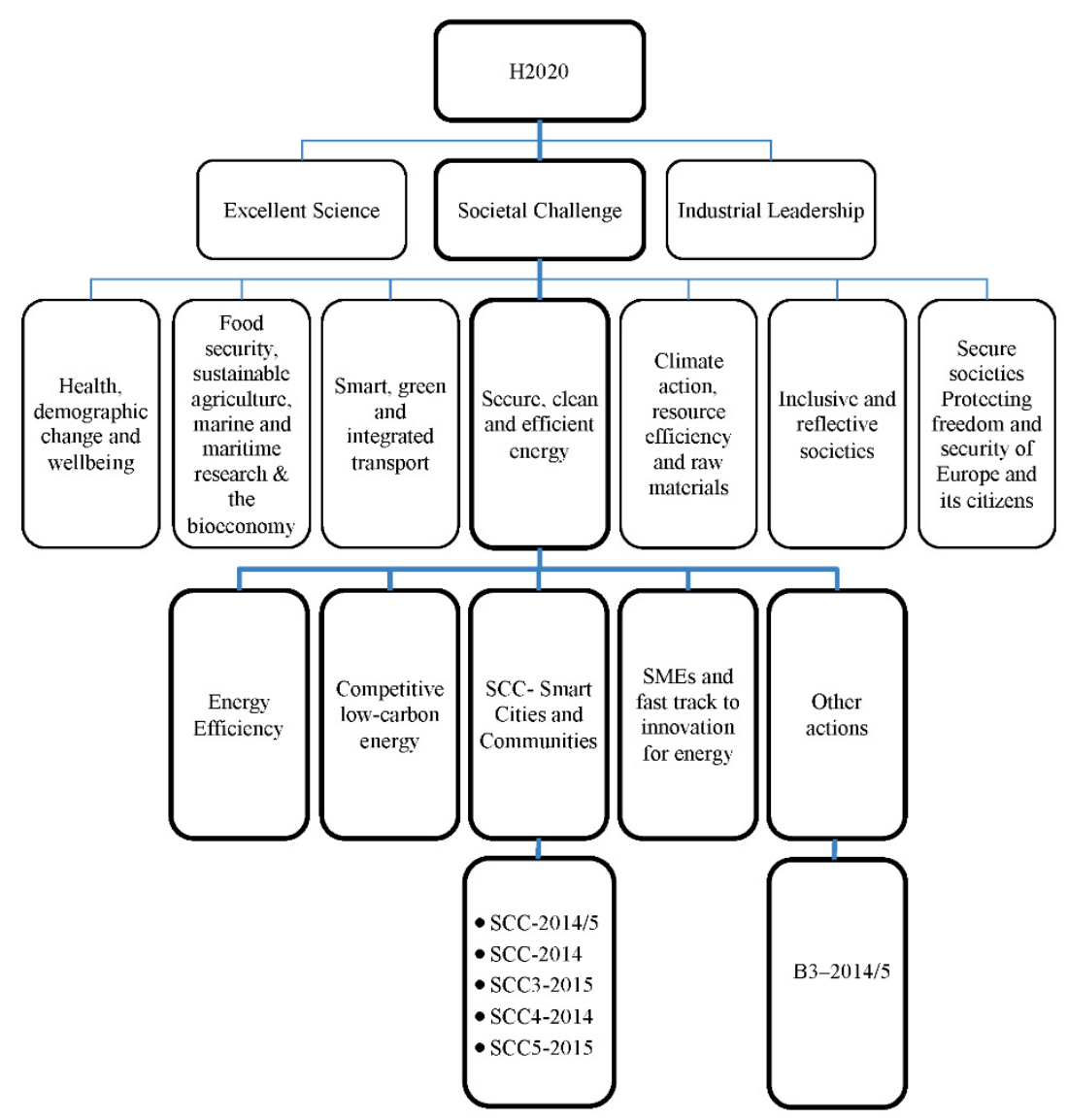

Figure 4: Horizon 2020 work programme 2014-2015. 


\section{References}

[1] Giffinger, R., Fertner, C., Kramar, H., Meijers, E. \& Pichler-Milanović, N., Ranking of European medium-sized cities, Final Report, Vienna, Centre of Regional Science (SRF), Vienna University of Technology, 2007, http:// curis.ku.dk/ws/files/37640170/smart_cities_final_report.pdf (last access June 2014)

[2] Copenhagen Cleantech Cluster, Danish Smart Cities: sustainable living in an urban world, Copenhagen Capacity, 2012, http:/www.cphcleantech.com/ media/2021654/smart\%20city\%20rapport_indhold_final_low.pdf (last access June 2014)

[3] ITU, International Telecommunication Union, Smart Sustainable Cities - An Analysis of Definitions - Draft version, ITU-T Focus Group (WG 1) on Smart Sustainable Cities, 2014, http://itu4u.wordpress.com/2014 /04/01/inviting-contributions-to-itu-reports-on-smart-sustainable-cities/ (last access, June 2014)

[4] EC, European Commission, Communication from the Commission - Europe 2020. A strategy for smart, sustainable and inclusive growth, 2010a, http:/eur-lex.europa.eu/LexUriServ/LexUriServ.do?uri=COM:2010:2020:

FIN:EN:PDF (last access May 2014)

[5] EC, European Commission, Communication from the commission smart cities and communities - European Innovation Partnership, 2012, http://ec.europa.eu/energy/technology/initiatives/doc/2012_4701_smart_ cities_en.pdf (last access May 2014)

[6] EC, European Commission, Leading the way in making Europe's cities smarter, 2013, Frequently asked questions. MEMO/13/1049, http://europa.eu/rapid/press-release_MEMO-13-1049_en.htm (last access June 2014)

[7] Hollands, R.G., Will the real smart city please stand up? City, 12,(3), pp. 303320, 2008

[8] Schaffers, H., Komninos, N., Pallot, M., Trousse B., Nilsson M. \& Oliveira A., Smart Cities and the Future Internet: Towards Cooperation Frameworks for Open Innovation, ed. J. Domingue et al., Future Internet Assembly, LNCS 6656, pp. 431-446, 2011

[9] MIT, 'Smart Cities Group', Cambridge, MA., 2013 http://smartcities.media .mit.edu/frameset.html (last access June 2014)

[10] Smart Cities Council. Smart cities readiness guide, The planning manual for building tomorrow's cities today, 2013, http://smartcitiescouncil.com/ (last access, June 2014)

[11] Treccani, Smart city. Lessico del XXI Secolo, 2013, http://www.treccani.it/ enciclopedia/smart-city_(Lessico-del-XXI-Secolo)/ (last access, June 2014)

[12] European Parliament, Mapping Smart Cities in the EU, Directorate general for internal policies, 2014, http://www.europarl.europa.eu/studies (last access, May 2014) 
[13] EC, European Commission, Digital Agenda for Europe (DAE), 2014, https://ec.europa.eu/digital-agenda/en/about-smart-cities (Last access, June 2014)

[14] EC, European Commission, Communication from the Commission to the European Parliament, the Council, the European economic and social committee and the committee of the Regions. Europe 2020 - Flagship initiative innovation union, 2010b, http://ec.europa.eu/research/innovationunion/pdf/innovation-union-communication_en.pdf (last access May 2014)

[15] EC, European Commission, Commission staff working document strategy for European Technology Platforms: ETP 2020, 2013, $\mathrm{ftp}: / / \mathrm{ftp}$.cordis.europa.eu/pub/etp/docs/swd-2013-strategy-etp-2020_en.pdf (last access May 2014)

[16] EC, European Commission, Outriders for European Competitiveness European Innovation Partnership as a tool for systemic change, 2014, http://ec.europa.eu/research/innovation-union/pdf/outriders_for_european_ competitiveness_eip.pdf (last access May 2014)

[17] EC, European Commission, European Innovation Partnership for Smart Cities and Communities, 2014, http://ec.europa.eu/eip/smartcities/aboutpartnership/how-does-it-work/index_en.htm (last access June 2014)

[18] EC, European Commission, European Innovation Partnership on Smart Cities and Communities, Strategic Implementation Plan, 2013, http://ec.europa.eu/eip/smartcities/files/sip_final_en.pdf (last access May 2014)

[19] EC, European Commission, European Innovation Partnership on Smart Cities and Communities, Operational Implementation Plan: First Public Draft, 2014, http://ec.europa.eu/eip/smartcities/files/operationalimplementation-plan-oip-v2_en.pdf (last access, June 2014)

[20] EC, European Commission, Invitation for commitment, 2014, http://ec.europa.eu/eip/smartcities/about-partnership/how-do-i-get-involved /index_en.htm (Last access, June 2014)

[21] EC, European Commission, Smart Cities Stakeholder Platform, Using EU funding mechanism for Smart Cities, 2013, http://eusmartcities.eu/sites/all/files/Guideline-Using\%20EU\%20fundings\%20 mechanism\%20for\%20smart\%20cities.pdf (last access, June 2014)

[22] EC, European Commission, Horizon 2020. Work Programme 2014-2015, 2013, 10. Secure, clean and efficient energy, http://ec.europa.eu/research /participants/data/ref/h2020/wp/2014_2015/main/h2020-wp1415-energy_en .pdf (last access June 2014) 